\title{
EFFECTIVE WEB SERVICE LOAD BALANCING THROUGH STATISTICAL MONITORING
}

\section{統計情報を用いた Web サービスの負荷分散}

\section{George Porter, and Randy H. Katz}

過負荷時の応答を改良するためにコンポーネント間の関連を特定する

Web サービスは eBay や amazon.com のよ うな Web ベースのポータルサイトにおいて, ますます広まってきている。これらは HTTP コンテナや Java ベースのアプリケーション である Beans，セッション管理機構といった ミドルウェアによって構成されている。これ らのコンポーネントは Web，アプリケーショ ン，データベースといった複数の層にまたが って提供されている。 Webサービスがより新 しく，精錬された機能を提供するようになる につれ，ミドルウェ アによるサービス の実現はより複雑 になる.今日のWeb サービスは多様な 種類のリクエスト とミドルウェアか らなっている。

Web サービスは 要求に応じてコン ポーネントを分 割・複製することに

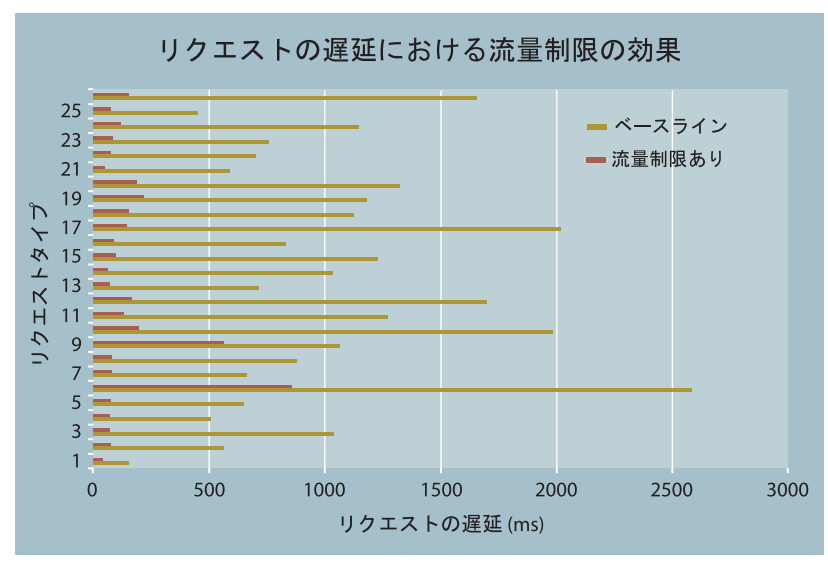

図 1。ボトルネックに関 係するリクエストの流量 を選択的に制限すると， ウェブサービスの平均応 答遅延は著しく減少す る.

モニタツールはこのような視覚的な情報を才 るからである.Web サービスにおいて， 異なったリクエス トは異なったコン ポーネントに対し て負荷を与える [1][3].さらに，ボ トルネックに最も 関連する要求を最 適化することは有 効である。この時,

リクエストとそ の効果の関係が 目に見えて分か る必要がある。 しかしながら， 現在のシステム ソフトウェアと 求に対して十分な応答を出来ない場合その システムの性能は不十分であるといえる。図 きるにもかかわらず，瞬間的なトラフィック は Web システムのミドルウェアのコンポー ネントに過唾な負荷を与える。システムが要 


\section{コンポーネント間の関連を見つけるために, それぞれの時点で収集 された大量のデータを調へるより洗練された方法が必要である.}

ペレータに対して提供していない. Web サー ビスが自己適応型となるためには，自己をよ り詳しく知っている必要がある. 内部のコン ポーネント間の関連を明らかにし，過負荷時 に Web サイトを利用する全てのユーザに不 利益を与えることなく負荷を減らすことがで きるような操作をオペレータに対して提供す る必要がある。

多くのリクエストに対して適切に対応する ことができる自己適応型の Web サービスを 設計するために, 我々は 4 種類の技術を提案 する. 多層システムにおいて要求の効果を明 らかにするための 単純な統計手法，ミ ドルウェアを監視 するためのブラッ クボックスアプロ 一チ, 意思決定を容 易にするための統 計情報をまとめた 可視化ツール，才ペ レータがそれらの結果に基づいた流入制御を 決定するための方法である。また，一連の手 順に人手が介在しているため, 㛜密には自己 適応型のシステムとは言えないこと付け加え ておく、我々はこれらのメカニズムを実現す るために RUBiS オークションサイト （rubis.objectweb.org）を提供している. RUBiS は eBayのようなオークションサイト の性能を測定するために設計された Web サ 一ビスのベンチマークである. 提案手法を適 用した結果，従来手法と比較して毎秒 $70 \%$ 以 上多くのリクエストに応答することが可能で ある. 加えて, ユーザに対するレイテンシを 最大 $78 \%$ 改善できる。これらの結果より，ミ ドルウェアを用いた Web サービスは自己適 応型のデザインの恩恵を受けることが分か る.

\section{関連研究}

我々はRUBiSを用いたJavaベースのミド ルウェアの性能を研究している. 以前, 我々
はワークロードがシステムのボトルネックを 決定するための重要な要素であることを示し た[1][3].

我々の手法はオペレーティングシステムと 3 層システムに制御の範囲が及ぶという点で 従来手法と異なる.ただし, システムへの要 求は均一であると仮定している. SWIFT シス テム[6][7]は，オペレーティングシステムに対 して I/O インターフェースを提供する.これ は，ミドルウェア間のインターフェースとも 相性がよい. ControlWare システム[10]は，3 層システムにおいてQoS要件を自動的に対応

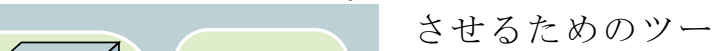
ルキットである。

Web サービスの 相関の解析のため の研究は数多くの 文献で発表されて おり, 実際の製品に も利用されている。 HP 研究所で行われ 困 2. Web 層, アプリ ケーション層, データ ベース層からなる複 雑な Web サービス た SLIC プロジェク ト[4]では, 細粒度の モニタリングとデ 一夕取得により

Service-Level Operations（SLOs）の違反を 引き起こすコンポーネントを特定できる.

IBM の Performance Management プロジェ クト[8][5]では, 制御理論と取得した情報の統 計処理を組み合わせることにより，予期しな いトラフイックの増加を検知し, 適切な状態 に順応させることができる、構造化されたデ 一タを可視化する技術としては[9]がある。

\section{自己適応型の Web サービスにおける過 負荷状態の回避}

Web サービスに寄せられるリクエスト数 が応答可能な許容值を超えた時, 過負荷状態 となる。トラフィックの急激な変動はシステ ム更新に比べて短い周期で発生する. オペレ ータは負荷を管理する多くの手段を持ってい る. そのひとつに負荷を複数のサーバに分散 
させる負荷分散と呼ばれる手法がある。ただ し, 複雑な Web システムは図 2 のように複数 のコンピュータを接続した複数レイヤ構造を しているため，このような環境下において負 荷分散を適用寸ることは自明なことではな い. というのは, 内部コンポーネントの詳細 なデータを取得し，それぞれに対して最適化 を行うことは難しいからである。

「HTTP 503 TOO BUSY」といった応答に より，一時的に負荷を軽減させることもでき る. しかしながら, これは少数の要求がボト ルネックとなっていた場 合であったとしても， Web サイト全体に影響を 与えてしまう。RUBiS を 用いたシミュレーション 結果では，たかだか $15 \%$ のリクエストがボトルネ ックを引き起こし，シス テム全体に影響を与え る.このような問題を解 決するために，適切な流 入制御を検討しなければ ならない。

選択的流入制御では， 過負荷を引き起こす 要因となるリクエス 卜に対して制御を行 う. 我々の評価結果に よると, データベース の CPU 負荷と応答に 必要なアイテムを探 す 2 種類のリクエス トがボトルネックと なることが分かった. 一般的に, 分散システ ムにおいて各コンポ

リクエストタイプ
BrowseCategories.php
BrowseRegions.php
SearchltemsByCategory.php
SearchltemsByRegion.php
AboutMe.php
RegisterUser.php
SellItemForm.php
Registerltem.php
Viewltem.php
PutComment.php
ViewUserlnfo.php
PutBidAuth.php
PutBid.php
BuyNowAuth.php
BuyNow.php
ViewBidHistory.php

表 1.ピアソン積率 相関係数で発見さ れたリクエストの ボトルネックに対 する影響. 太字の工 ントリは統計的に 重要で正の相関を 持っている。これら は選択的流入制限 の対象となる候補 である。

ーネント間の実行時の関係を決定することは 非常に難しい．これらはワークロードによっ て決定し，また時間経過によっても変化する ためである。通信の不明瞭さに加えて, リク エストからボトルネックへの対応付けは自明 ではない。このような問題に対し, 我々は測 定したデータを利用し，リクエストとボトル ネックの関連を求める.

問題設定 : システムのボトルネックとなる コンポーネント C が与えられ， C に関連する
リクエストを特定する。使用するデータは最 小限に抑えるべきである. 関連する要求を特 定後, システムが過負荷状態にならない範囲 まで $\mathrm{C}$ に関連するリクエストの数を減少させ る.

以降, 我々が提案する手法の詳細について 述べる.

\section{ボトルネックに関連する要求の除去}

リクエストが Web サーバに到達すると, ア プリケーション層において1つあるいは複数

\begin{tabular}{|r|r|}
\hline P値 & 相関係数 \\
\hline 0.1747 & -0.035 \\
0.0926 & -0.0434 \\
\hline 0 & 0.5654 \\
0.0034 & 0.0756 \\
0.7702 & 0.0075 \\
0.4876 & -0.0179 \\
0.4891 & 0.0179 \\
0.8767 & 0.004 \\
0.0953 & -0.0431 \\
\hline 0.5157 & -0.0168 \\
0.4646 & -0.0189 \\
0.8641 & -0.0044 \\
0.2566 & -0.0293 \\
\hline 0.971 & -0.0009 \\
\hline 0.1206 & 0.0401 \\
\hline 0.9741 & -0.0008 \\
\hline
\end{tabular}

の Java コンポーネント による処理が呼ばれる. データベースへのアクセ ス処理や直接結果を返す 処理がこれにあたる。各 サーバ上でログや状態を 取得することが可能であ ったとしても, システム 全体を一度に把握するた めの良いシステムツール は存在しない。我々は, リクエストとその応答間 の相関関係を明らかにす るために, 取得した大量 のデータを解析するための方法を考えなけれ ばならない。

どのリクエストがボトルネックになってい るかを知るために, sysstat ツールによって取 得する CPU 負荷情報や apache が収集する口 グを使用する. 我々は, リクエストの種類と CPU 負荷の関係を見るためにピアソン積率 相関関数を使用する. ピアソン積率相関関数 は計算が容易であり, 実際の場面において比 較的良い結果を得ることができることが知ら れている. 我々は以下のような手法でログの 統計処理を行う.

1. apacheのログをある時間間隔 $\mathrm{T}_{\mathrm{int}}$ に分 割する。今回は $\mathrm{T}_{\mathrm{int}}$ を 1 秒とした。

2. 各時間間隔に寄せられたリクエストの 回数をその種別に応じて数える.

3. $\mathrm{n}$ を時間間隔数， $\mathrm{m}$ を種別に応じたリ クエストの回数とし, $\mathrm{n}^{*} \mathrm{~m}$ の行列 $\mathrm{M}$ を 定義する. 行列要素 $\mathrm{M}(\mathrm{i}, \mathrm{j})$ はある時刻 $\mathrm{i}$ にタイプ j のリクエストが発生した回 数を表す. 
データベースの負荷を観測することにより CPU 負荷ベクトルを作成する. 作成した行列 $\mathrm{M}$ の列要素と CPU 負荷ベクトルより相関関 係を見つける。 これはディスク $\mathrm{I} / \mathrm{O}$ などのボ トルネックを探す際に頻繁に利用される手法 と同じである. 結果を表 1 に示す。ここで, 特に重要となるリクエストを太字で強調して ある。この太字で強調されているリクエスト は流入制御の対象となる候補である. 我々は, 多くのリクエストと CPU 負荷に関連がある と予測していた。例えば， BrowseCategories.php なども制御の対象に なると考えていた。しかしながら，実際には 僅か 2 つのリクエストのみが対象となった. とはいえ, 要求の種類は少ないもののこれら のリクエストはデータベース負荷の大部分を 占める. 巨大なシステムにおける問題のひと つに, 関連の低い相関関係をどのように取り 除くかという事が挙げられる. 数多くのシス テム評価指標が与えられると, 多くのシステ ムのコンポーネントやリクエストの種類に関 連すると考えられる. 学習モデルを用いてこ れを管理することも可能であるが，これは本 記事の範囲を超える.

\section{ブラックボックス化したコンポーネント の監視}

自己適応型のシステムはそのアルゴリズム を利用するためにモニタ情報を必要とする. この時, モニタより取得する情報はできる限 り少ない方が好ましい. ブラックボックス化 する理由として, 少なくとも以下に示す 3 点 が挙げられる.

運営しているサービスの中断に対する懸念 我々のシステムを巨大な Web システムに 適用することについて議論した所, システム オペレータは「私たちは実験室のプロジェク

トではなく, できる限り長い期間の動作を保 証した実際のアプリケーションに興味があり ます。したがって, 実際に実現可能なサービ スかどうかに注意するべきです」と答えた。 そのため, 我々は簡単にアクセス可能で日常 的に取得可能なデータを用いた統計分析を行 う. 具体的には, apacheによって生成される ログや sysstat によって取得可能なデータを
使用する．ファイルシステムとシステムコー ルのインターフェースのようなオペレーティ ングシステム特有のコンポーネントに対する 作業の多くはシステムにより異なった作業を 必要とする.つまり, 専門知識が必要となる. ソフトウェアやハードウェアの更新は頻繁に 発生し, 低レベルでコードを記述する場合, コンポーネントの変更や更新のたびにこれら の書き換えが必要となる.これは非常に煩雑 である。

\section{急速に変化するサービス}

今日の Web サービスは急速に変化してい る. Web サイトの機能は到着するパケットパ ターンと同様に変化する. 大規模な Web サイ トではハードウェアとソフトウェアの更新が 定期的に行われるので, システムの更新のた びにオペレータは流入モニタシステムや計装 システムを再構成しなければならない。これ はオペレータにとって非常に手間がかかる. 我々は各コンポーネントをブラックボックス として扱うことにより, ファイルシステムや OS のシステムコール, その他のフック関数な ど個々のコンポーネントについては変更を必 要としない. これにより, 高い可搬性を持た せることができ, システムの更新による影響 を少なくすることができる.

\section{コンポーネントの所有権の分散}

サービスの種類によっては, サイトの管理 は数人のオペレータによって行われるかもし れない. このように複数人での監視操作の調 整は難しい，高レベルでの測定に焦点を当て ることにより, 異なったグループではソフト ウェアの更新とシステム変更を調整する必要 がない.さらに，オープンソースでないコン ポーネントに対しての測定は不可能かもしれ ない。

高レベルでの測定は相関関係を特定するた めに有効であり, 実行システムの性能を大い に改善することが期待できる.

\section{自動的に過負荷状態を緩和するための可 視化ツール}


以下では，一連の作業中にオペレータが介 在する自己適応型の Web サービスシステム を考える.コンポーネントと負荷の基本的な 関係を明瞭に可視化することによって，オぺ レータが的確に意思決 定できる. 図 3 に我々 が提案する可視化の例 を示す。ここで円グラ フはボトルネックとな るトラフィックの割合 を示している. ボトル ネックに関連するトラ フィックについては, そのリクエストの種類 を列挙している。この 簡単なグラフに よりオペレータ は選択する流入 制御によって総 トラフィック量 の何パーセント にどの程度の影 響が出るかを判 断することができる.

前節で述べた 3 つの問題点とその解決のた めに, 可視化が必要となる. これにより, オ

図 3. 可視化ツールが選 択的流入制限の候補と 認識されたリクエスト を示している.グラフの 数字は総リクエス卜数 における比率である。
つの情報に関連付けてシステムオペレータに 与えることができる.

\section{流入制御に効果的な装置}

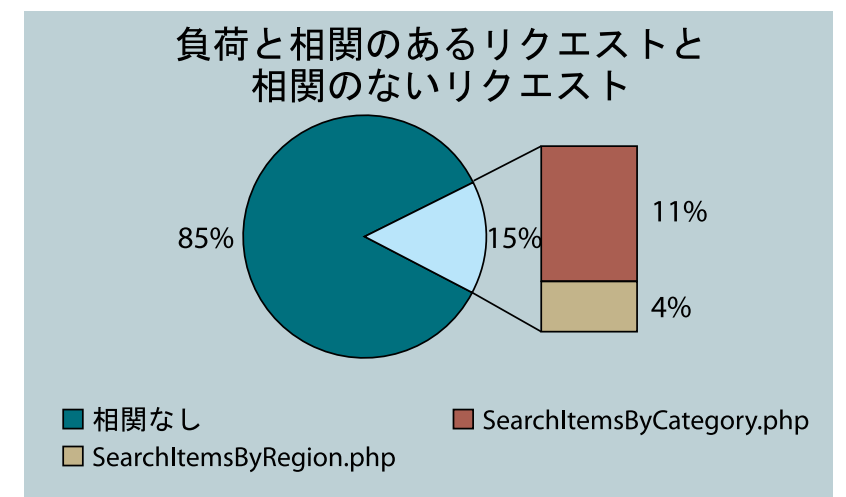

選択的流入 制御のために 対象となるリ クエストが特 定されると，才 ペレータはこ のリクエスト の頻度を下げ るための手法 が必要となる. これは, HTTP

レベルで方法, ネットワークレベルでバンド 幅に制限を加える方法により実現することが できる，我々は，Web 層の変更を必要としな いネットワークレベルでの流入制御を用い る。負荷と相関のあるリクエストをバンド幅 制限のあるネットワーク経路上に送信する。 これにより, エンドユーザへの応答は, 制御 前と比べて長くなる. 寸なわち, 複数のリク エストで構成されるセッションに要する時間 が流入制御実行前と比較して長くなるかもし ペレータに対して 問題の原因追求の ために必要な情報 や性能情報を提供 し, 過負荷状態とな る可能性を減少さ

\begin{tabular}{|c|c|c|c|c|c|}
\hline シナリオ & $\begin{array}{c}\text { 総リクエ } \\
\text { スト数 }\end{array}$ & $\begin{array}{c}\text { 負荷と } \\
\text { 相のあ } \\
\text { URL数 }\end{array}$ & $\begin{array}{l}\text { リクエス } \\
\text { 卜数/秒 }\end{array}$ & $\begin{array}{l}\text { 平均セッ } \\
\text { ショシ時 } \\
\text { 間（秒） }\end{array}$ & \begin{tabular}{|l} 
最大リク \\
エスト \\
時間 (秒)
\end{tabular} \\
\hline 標準設定 & 756,137 & $\begin{array}{l}112,521 \\
(14.9 \%)\end{array}$ & 462 & 670 秒 & 154.7 秒 \\
\hline $\begin{array}{l}\text { 選択的 } \\
\text { 流量制限 } \\
\text { あり }\end{array}$ & $1,143,264$ & $\begin{array}{c}105,964 \\
(9.3 \%)\end{array}$ & 782 & 872 秒 & 32.7 秒 \\
\hline
\end{tabular}

せる.まず，オペレータがツールにより適切 な状態にあると判断すると, この状態の処理 を自動化することができる．第 2 に，急速な サービスの変更に対応するために, オペレー 夕に知らされているビジネスルールに従って 流量制限を実施するかどうか可視化ツールに より決めることができる。一方で，ツールが 頻繁に使用されるような場合, その都度才ぺ レータが関与することなく自動的に動作する ようなプログラムが作成されているかもしれ ない. 最後に, コンポーネントの所有権の分 散についてである. 可視化要求をシステム内 で許可することにより，異なった管轄（例え ば，企業の異なる部門など）の測定結果を 1
表 2 . 標準設定と選択 的流量制限を施した 設定の性能比較.

3,500 クライアントか らの 30 分間の同時ア クセスで計測してい る. セッションはオー クションの一連の操 作を表す.

れないことを意味 する.

可視化ツールと 実際の流入制御の 動作を結びつける ために, 統計的情報 の解析結果より発 見されたボトルネ ックを解消するた めのインターフェ 一スを考える.この 表示方法として, 我々が述べたグラ フと似たものを考 える.図 3 の棒グラ フによって負荷に 関連するリクエス 卜を特定することができるだろう。このよう な特定を行った後, 流入制御のためのフィル タを Web サーバ (HTTP ベースで流入制御を 行う場合）やネットワーク機器（ネットワー クレベルで流入制御を行う場合）に送信する. 


\section{自己適応型のシステムは統計的アルゴリズムを適用するために モニタ情報を必要とするが，このモニタ情報の取得がシステムに 与える影響は最小限に抑えるべきである.}

いずれの場合においても, オペレータはボト ルネックと到着するパケットのトラフィック の両者に対して，その効果を確認するための 手段を持っているはずである.

\section{評価結果}

我々は，本記事で述べた 4 つの方法につい て RUBiS オークションサイトの Web サー ビスに適用し，評価を行った。評価環境とし て, IBM BladeCenter と 2 つの Nortel Layer 2-7 ギガビットスイッチから成るシステムを 構築した. Nortel のスイッチはギガビットレ ートで HTTP のリクエストタイプ (URL パ ターンマッチングに基づいて判断する）を特 定し, 流入制御の対象となるパケットへ VLAN タグを割り当てることができる。これ により，より詳細な流入制御を行うことが可 能となる. バンド幅を削減するために, Linux Traffic Control（tc）拡張を使用し, 対象とな るパケットのビットレートを基本レートであ る 3. $5 \mathrm{Mbps}$ から $1 \mathrm{Mbps}$ に下げる。

図 1 と表 2 が示すように，選択的流入制御 を実行することによりボトルネックとなるリ クエストとは関係のないユーザにとっての性 能が大幅に向上する. 我々の評価では, 1 秒 間に処理するリクエストの数が 462 回から 782 回に増加した。これは, ボトルネックと なる非常に負荷の大きい処理の回数が減少す るためである。したがって，いくつかの連続 した要素を探索するためにかかる時間は長く なる.これは，平均セッション時間が 670 秒 から 872 秒に増加したことからも分かる. 毎 秒のリクエスト処理数の増加と最大の応答時 間の短縮という正の効果からも分かるよう に，特定パケットのビットレートを下げるこ とにより Web サイトの訪問者に対して多大 な恩恵をもたらす。

\section{まとめ}

我々は「多層システムにおいて要求の効果 を明らかにするための単純な統計的手法」 「ブラックボックス化したコンポーネントの 監視手法」「統計的手法の結果をまとめるた めの可視化ツール」「流入制御を決定するた めの効果的な方法」といった 4 種の技術から 成る自己適応型の Web サービスの構築手法 を提案した。我々はオークションシステムを 提供する Web サービスにこれらの技術を組 み込み, 予備評価を行った. その結果, 1 秒 間に処理可能なページ数が $70 \%$ 増加し, ユー ザが Web サイトにアクセスした際の最大の 遅延を 78\%削減する事ができた。これらの結 果より, 自己適応型の Web サービスの構築 ・ 展開がますます広まるものと期待される.

\section{文献}

1. Amza, C., Cecchet, E., Chanda, A., et al. Specification and implementation of dynamic Web site benchmarks. In Proceedings of IEEE 5th Annual Workshop on Workload Characterization (WWC-5), (Austin, TX, Nov. 2002).

2. Bhatti, N., Bouch, A., and Kuchinsky, A. Integrating user-perceived quality into Web server design. In Proceedings of the 9th International World Wide Web Conference (WWW9), (Amsterdam, The Netherlands, May 2000).

3. Cecchet, E., Chanda, A., Elnikety, S., et al. Performance comparison of middleware architectures for generating dynamic Web content. In Proceedings of the 4th ACM/IFIP/USENIX International

Middleware Conference, (Rio de Janeiro, Brazil, June 2003).

4. Cohen, I., Chase, J.S., Goldszmidt, M., et al. Correlating instrumentation data to system states: A building block for 
automated diagnosis and control. In Proceedings of the 6th Symposium on Operating Systems Design and Implementation (OSDI 'O4), (San Francisco, CA, Dec. 2004).

5. Diao, Y., Lui, X., Froehlich, S., et al. On-line response time optimization of an Apache Web server. In Proceedings of the 11th International Workshop on Quality of Service (IWQoS '03), (Monterey, CA, June 2003).

6. Goel, A., Steere, D., Pu, C., et al. Adaptive resource management via modular feedback control, 1999.

7. Goel, A., Steere, D., Pu, C., et al. Swift: A feedback control and dynamic reconfiguration toolkit. Technical Report CSE-98-009, Oregon Graduate Institute, Portland, OR, June 1998.

8. Lassettre, E., Coleman, D.W., Diao, Y., et al. Dynamic surge protection: An approach to handling unexpected workload surges with resource actions that have lead times. In Proceedings of the 14th IFIP/IEEE International Workshop on Distributed Systems: Operations and Management
(DSOM 2003), (Heidelberg, Germany, Oct 2003). LNCS, Vol. 2867, Springer, 82-92.

9. Tufte, E. Envisioning Information. Graphics Press, 1990.

10. Zhang, R., Lu, C., Abdelzaher, T., and Stankovic, J. Controlware: A middleware architecture for feedback control of software performance. In Proceedings of the 22nd International Conference on Distributed Computing Systems (ICDCS 2002), (Vienna, Austria, July 2002).

George Porter (gporter@cs.berkeley. edu） は,カリフォルニア大学バークレー校 のコンピュータサイエンス分野の博士課程 の学生である。

Randy H. Katz (randy@cs.berkeley. edu）は 1983 年よりカリフォルニア大学バ ークレー校のコンピュータサイエンス分野 の教員であり，現在は United Microelectronics 社の教授も兼任してい る.

訳 : 木村英明（筑波大学・システム情報工 学研究科) 